\title{
Effect of Acarbose on Exocrine and Endocrine Pancreatic Function in the Rat
}

\author{
M. Otsuki, C.Sakamoto, A. Ohki, Y.Okabayashi, I.Suehiro and S. Baba \\ Second Department of Internal Medicine, Kobe University School of Medicine, Kobe, Japan
}

\begin{abstract}
Summary. Exocrine and endocrine pancreatic function were studied simultaneously in the isolated perfused pancreas from rats fed a normal or an acarbose-containing diet $(150 \mathrm{mg} /$ $100 \mathrm{~g}$ food) for 20 days. Body weight gain of acarbose-treated rats was slightly lower than that of control rats, despite a larger food intake. Basal and caerulein-stimulated flow rates of pancreatic juice from acarbose-treated rat pancreases were similar to those from controls, suggesting that the treated rat pancreas has normal sensitivity and responsiveness to caerulein. On the other hand, amylase output in response to caerulein was significantly decreased in acarbose-treated rat pancreases, though basal output was normal. The addition of acarbose to the diet for 20 days had no effect on the speed of
\end{abstract}

the insulin response to glucose and caerulein, but the magnitude of insulin secretion to glucose stimulation was reduced by $40 \%$ and the caerulein-induced additional output of insulin by $30 \%$ in the treated group as compared with the control group. The present investigation has demonstrated that inhibition of key enzymes for carbohydrate digestion decreases not only the secretory responsiveness of amylase from acinar cells to caerulein stimulation but also the sensitivity of the insulin-secretory mechanism of pancreatic B cells to glucose and non-glucose stimulation.

Key words: Acarbose, rat perfused pancreas, insulin secretion, amylase output.
Acarbose, a complex oligosaccharide, is a potent inhibitor of glucoside hydrolases and decreases post-prandial hyperglycaemia when administered with food [1-5]. Furthermore, attenuation of insulin and gastric inhibitory polypeptide (GIP) release in response to a sucrose load by acarbose has been described in man and animals [3-11]. However, the mechanism by which feeding acarbose affects the insulin response to sucrose remains to be clarified. Moreover, the effect of long-term inhibition of the key enzymes for carbohydrate digestion of insulin release by B cells and the exocrine pancreas is not fully understood.

Glucose-dependent insulin release is known to be highly sensitive to relatively short periods of fasting [8-12]. In intact rats, the plasma insulin response to intravenous stimulation with either glucose, tolbutamide or glibenclamide is reduced by $50 \%-80 \%$ during $16 \mathrm{~h}$ fasting without affecting the extractable insulin content of the pancreas [9]. In animals and in man, fasting makes B cells secrete less insulin than normal in response to glucose [8-12]. Total blunting of the response was observed in rats deprived of food for 5 days [13]. Moreover, persistent and progressive impairment of insulin secretion has been noted in rats on a low carbohy- drate diet [8]. From these observations, it is conceivable that blunting of the insulin response to sucrose is induced either by the flattened glucose curve due to inhibition of sucrose or by impairment of the insulin releasing mechanism of the $B$ cell due to a long-term inhibition of post-prandial glycaemia.

The present study was undertaken to determine whether an attenuation of post-prandial hyperglycaemia by feeding acarbose with food has any effects on insulin secretory response to glucose and non-glucose stimulation and on pancreatic exocrine function.

\section{Materials and Methods}

Male Wistar rats weighing about $240 \mathrm{~g}$ were kept at $23^{\circ} \mathrm{C}$ on a $12 \mathrm{~h}$ light and dark cycle with free access to water. Animals were adapted to a standard powder diet for 5 days and then fed ad libitum (either a control diet or the same diet containing $150 \mathrm{mg}$ acarbose $/ 100 \mathrm{~g}$ food for 20 days). The standard rat diet contained $7.0 \%$ water, $24.1 \%$ protein, $4.6 \%$ fat, $7.1 \%$ ash, $4.2 \%$ fibre and $53.0 \%$ nitrogen free extracts of which $45 \%$ was carbohydrate consisting of corn-starch $(35 \%)$ and $\alpha$ starch (10\%) (Oriental Yeast Company, Tokyo, Japan). Acarbose as a lyophilized powder (provided by Bayer Yakuhin, Osaka, Japan) was mixed thoroughly with the standard powder diet, which ensured that the animals received the drug each time they ate. Each rat was housed 
in an individual metabolic cage and its weight and food consumption measured daily. After each rat had been on its diet for 20 days, the pancreas was isolated and perfused by the procedure reported previously [14]. All perfusions were performed with Krebs-Ringer bicarbonate buffer containing $0.25 \%$ bovine serum albumin (fraction V, Armour Pharmaceuticals, Phoenix, Arizona, USA), 4.6\% Dextran T-70 (Pharmacia Fine Chemicals, Uppsala, Sweden) and $2.8 \mathrm{mmol} / 1$ glucose. The medium was equilibrated with $95 \% \mathrm{O}_{2}$ and $5 \% \mathrm{CO}_{2}$ and maintained at $\mathrm{pH} 7.4$ at $37^{\circ} \mathrm{C}$. The superior mesenteric and caeliac arteries were used as the inlets of the vascular perfusion, and the portal vein as the outlet. The flow rate through the pancreas was kept constant at $2 \mathrm{ml} / \mathrm{min}$. After a single passage through the pancreas, the complete effluent was collected at 1 min intervals in chilled tubes for the measurement of insulin concentration.

To measure pancreatic exocrine secretion, a calibrated capillary tube was attached to the free end of a pancreatic cannula inserted into the distal end of the common duct at a point shortly before its entrance into the duodenum. The proximal end of the bile duct was ligated. The flow rate of the pancreatic juice was measured by changing the capillary tube every $10 \mathrm{~min}$. The sample of pancreatic juice was diluted with $5 \%$ bovine serum albumin and stored at $-20{ }^{\circ} \mathrm{C}$ until the assay of amylase concentration.

The experiments were performed after a 40 -min equilibration period. The glucose concentration was then changed to $8.3 \mathrm{mmol} / 1$ for $50 \mathrm{~min}$ by changing the medium reservoir. Ten minutes later, synthetic caerulein (Kyowa Hakko Kogyo, Tokyo, Japan) was added at a concentration of $0.1 \mathrm{ng} / \mathrm{ml}(64 \mathrm{pmol} / 1)$ for $20 \mathrm{~min}$. Caerulein $(0.1 \mathrm{ng} / \mathrm{ml})$ is the minimal effective concentration which will elicit the maximal secretory response in pancreatic juice flow rate and amylase output [14]. Synthetic caerulein was used as a non-glucose stimulant for endocrine secretion because it has similar biological actions on exocrine and endocrine secretion to those of natural porcine $\mathrm{CCK}$ [14-16].

Amylase activity in the 10-min aliquots of pancreatic juice was determined by a chromogenic method with blue-dyed starch polymer [17]. Amylase output was expressed as Somogyi units per $10 \mathrm{~min}$.

Immunoreactive insulin (IRI) in the portal effluent was measured by polyethyleneglycol radioimmunoassay [18] using crystalline rat insulin as a reference standard.

Statistical analysis was carried out by using Student's t-test for unpaired samples. Results are expressed as mean \pm SEM.

\section{Results}

Body weight increased with time in both control and acarbose-treated groups. No significant differences between groups were found for the body weights before (control: $244 \pm 6.5 \mathrm{~g}$ versus treated: $242 \pm 4.4 \mathrm{~g}$ ) or after treatment (control: $350 \pm 14.3 \mathrm{~g}$ versus treated: $324 \pm$ $7.4 \mathrm{~g}$ ), although the body weight gain of rats fed the acarbose-containing diet was slightly lower than that of control rats. However, food intake of rats treated with the acarbose-containing diet was significantly greater than those given the control diet $(26.6 \pm 0.8$ versus $22.3 \pm 1.8 \mathrm{~g} /$ day; $p<0.05$ ). Thus, the ingested dose of acarbose per rat per day was about $40 \mathrm{mg}$ (about $150 \mathrm{mg} / \mathrm{kg}$ body weight), which is $25-50$ times as great as that used in human therapy [3-7]. Pancreatic wet weight was similar in the control and treated groups (control: $1.15 \pm 0.05 \mathrm{~g}$ versus treated: $1.18 \pm 0.06 \mathrm{~g}$ ).

The effect of synthetic caerulein on the time-course of pancreatic juice flow and amylase output from isolated perfused pancreases prepared from fed rats treated with or without acarbose is shown in Figure 1. Basal and caerulein-stimulated flow rates of pancreatic juice from rats given the acarbose-containing diet for 20 days were similar to those from control pancreases (Fig.1). The cumulative output of pancreatic juice during a 20min stimulation with $0.1 \mathrm{ng} / \mathrm{ml}$ caerulein from the acarbose-treated and control groups was $48.3 \pm 4.6$ and $55.4 \pm 6.2 \mu \mathrm{l} / 20 \mathrm{~min}$, respectively. On the other hand, caerulein-stimulated amylase output from the acarbosetreated group was significantly lower than that from the control group, although basal output was similar (Fig.1). The cumulative output of amylase for $20 \mathrm{~min}$ during caerulein stimulation from rats fed a normal or
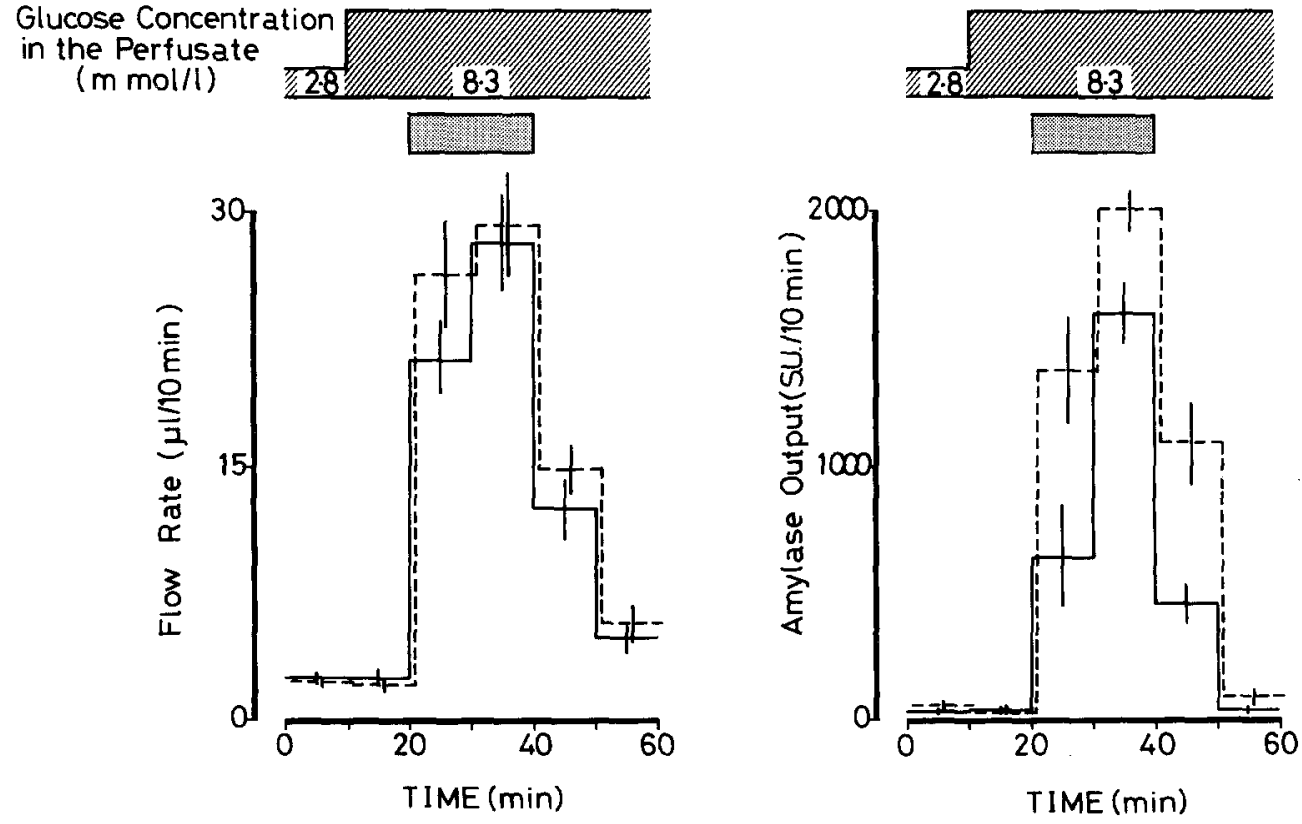

Fig. 1. Time-course of pancreatic juice flow (left panel) and amylase output (right panel) in response to a 20 -min perfusion with $0.1 \mathrm{ng} / \mathrm{ml}$ caerulein (圈) in the presence of $8.3 \mathrm{mmol} / 1$ glucose (שz). Pancreas were isolated and perfused from rats fed a standard powder diet with (_) or without (--) acarbose $(150 \mathrm{mg}$ / $100 \mathrm{~g}$ food) for 20 days. The flow rate of pancreatic juice was measured every $10 \mathrm{~min}(\mu \mathrm{l} / 10 \mathrm{~min})$ and the amylase output was expressed as Somogyi units (SU) $/ 10 \mathrm{~min}$. Each value represents the mean \pm SEM of eight experiments 
Glucose Concentration in the Perfusate

( $\mathrm{m} \mathrm{mol} / \mathrm{l}$ )

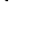
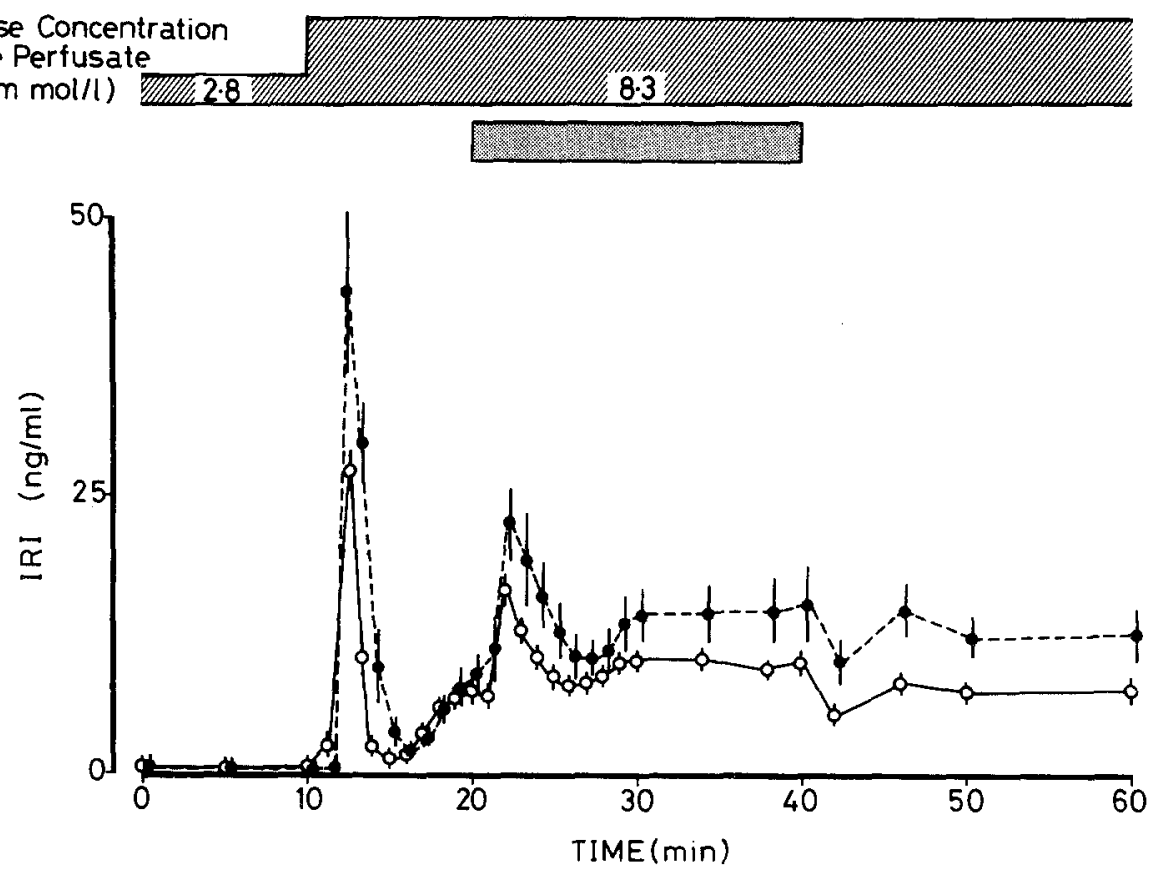

Fig. 2. Time-course of immunoreactive insulin (IRI) release in response to $8.3 \mathrm{mmol} / 1$ glucose (ש) and $0.1 \mathrm{ng} / \mathrm{ml}$ caerulein stimulation (娄). Pancreases were isolated and perfused from rats fed a standard powder diet with $(\mathrm{O}-\mathrm{O})$ or without (---) acarbose $(150 \mathrm{mg}$ / $100 \mathrm{~g}$ food) for 20 days. Each value represents the mean \pm SEM of eight experiments. Flow rate of pancreatic juice and amylase output (Fig. 1) and the IRI response were measured simultaneously in the same experimental preparations an acarbose-containing diet was $3524 \pm 211$ and $2236 \pm 276$ Somogyi units $/ 20 \mathrm{~min}(p<0.001)$, respectively.

The time-course of IRI secretion in response to glucose and caerulein from isolated perfused pancreases prepared from acarbose-treated and control rats was similar. A sharp rise in IRI release was observed in the first 1-min sample after increasing the glucose concentration from 2.8 to $8.3 \mathrm{mmol} / 1$ and after the addition of $0.1 \mathrm{ng} / \mathrm{ml}$ caerulein (Fig. 2). Both the peak IRI response and the cumulative IRI output over $5 \mathrm{~min}$ (from 11 to $15 \mathrm{~min}$ ) in response to $8.3 \mathrm{mmol} / 1$ glucose were reduced by $40 \%$ in the acarbose-treated rats (peak $27.0 \pm 1.7 \mathrm{ng} /$ $\mathrm{ml}$, cumulative output $96.0 \pm 6.8 \mathrm{ng} / 5 \mathrm{~min}$ ) compared with the control group (peak $44.7 \pm 7.5 \mathrm{ng} / \mathrm{ml}: p<0.01$, cumulative output $173.6 \pm 36.2 \mathrm{ng} / 5 \mathrm{~min} ; p<0.05)$. IRI output during the first $5 \mathrm{~min}$ of stimulation with $0.1 \mathrm{ng} / \mathrm{ml}$ caerulein from the rats fed a normal or an acarbose-containing diet was $163.4 \pm 30.9$ and $111.0 \pm$ $6.2 \mathrm{ng} / 5 \mathrm{~min}(p<0.05)$, respectively. The total IRI output over $20 \mathrm{~min}$ of caerulein stimulation from the treated group $(401.7 \pm 18.0 \mathrm{ng} / 20 \mathrm{~min})$ was slightly lower than that obtained from the control group (573.1 \pm $122.7 \mathrm{ng} / 20 \mathrm{~min} ; p>0.05)$. The magnitude of the early and late insulin secretory phases in response to caerulein from the acarbose-treated rat pancreases were both reduced by $30 \%$. However, these differences were not statistically significant.

\section{Discussion}

Treatment with acarbose, a potent inhibitor of intestinal $\alpha$-glucoside hydrolases [1, 2], for 20 days produced an effect on pancreatic amylase secretion that was quantitatively but not qualitatively different from rats given a control diet. Pancreatic juice secretion evoked by chole- cystokinin (CCK) and other pancreatic acinar stimulants, such as caerulein and acetylcholine [14, 15, 19], can be clearly separated from secretin-stimulated fluid secretion by its independence of extracellular bicarbonate [19]. Since there is no evidence for an action of $\mathrm{CCK}$ on duct cells [20], bicarbonate-independent fluid secretion is thought to occur in the acinar cells and may reflect acinar cell function $[19,20]$. Therefore, a normal secretory pattern of pancreatic juice in response to caerulein suggests normal acinar cell function. Based on these observations, together with the present data on caerulein-evoked fluid secretion, the sensitivity and the responsiveness of the exocrine pancreas of acarbosetreated rats are assumed to be no different from those of control pancreases. Thus, the decreased output of amylase is assumed to be due to a decreased production of enzyme, rather than alteration in the secretory mechanism. In our preliminary experiments in rats fed on acarbose-containing diet for 10 days, a reduction of amylase activity in the pancreas was observed in both fasted rats and rats maintained on a low carbohydrate diet [21-25]. The dietary induced modifications in enzyme composition of the pancreas are well-recognised as a pancreatic adaptation to the diet $[21-25] \leqslant$ The rats given an acarbose-containing diet would be the same as those maintained on a low carbohydrate diet, because long term inhibition of the key enzymes for carbohydrate digestion may result in carbohydrate malabsorption similar to sucrose-isomaltase deficiency [26].

The effect of acarbose ingestion on the insulin secretory response to glucose is similar to the results of earlier studies in man and animals given a low carbohydrate diet $[8,11,27]$. Feeding an acarbose-containing diet for 20 days had no effect on the speed of the insulin response to glucose and caerulein, but the magnitude of the insulin secretion was reduced. In the present perfu- 
sion experiments with pancreases from fed animals, treatment with acarbose reduced the insulin response to glucose by $40 \%$ and the caerulein induced additional output of insulin by $30 \%$. Although caerulein can elicit insulin release in the absence of glucose [14], its predominant action consists of enhancing all aspects of glucose-induced insulin secretion $[14,16]$.

Fölsch et al. [6] observed that the addition of acarbose to a sucrose load attenuates sucrose-induced glycaemia and the insulin response, and completely abolishes GIP release. From these experiments, the decreased insulin response to sucrose with acarbose has been related to both the flattened glucose curve and the attenuated GIP release [6]. The present investigation extends these observations by demonstrating that longterm inhibition of the key enzymes for carbohydrate digestion decreases the sensitivity of the insulin-secretory mechanism of the B cells to both glucose and non-glucose stimulation. However, the reduced sensitivity of acarbose-treated rats may not necessarily indicate inhibition of $B$ cell function. It could also imply a passive return to a low intrinsic basal level of sensitivity due to a lack of stimulation from meals. In fact intermittent pulsing of fasted rats with hyperglycaemic episodes produced by the injection of calorically insignificant amounts of glucose intraperitoneally ameriolated the impairment of glucose-stimulated insulin secretion characteristic of the fasting state [8].

Thus, the present results suggest that the addition of acarbose to the diet at a relatively high dose decreases not only the secretory responsiveness of amylase from acinar cells to caerulein stimulation, but also the sensitivity of the insulin-secretory mechanism of B cells to glucose and non-glucose stimulation.

\section{References}

1. Schmidt DD, Frommer W, Junge B, Müller L, Wingender W, Truscheit E, Schäfer D (1977) $\alpha$-glucosidase inhibitor. New complex oligosaccharides of microbial origin. Naturwissenschaften 64: $535-536$

2. Caspary WF, Graf S (1979) Inhibition of human intestinal $\alpha$-glucoside-hydrolases by a new complex oligosaccharide. Res Exp Med 175:1-6

3. Hillebrand I, Boehme K, Frank G, Fink H, Berchtold P (1979) The effects of the $\alpha$-glucosidase inhibitor Bay g 5421 (acarbose) on meal-stimulated elevations of circulating glucose, insulin, and triglyceride levels in man. Res Exp Med 175: 81-86

4. Hillebrand I, Boehme K, Frank G, Fink H, Berchtold P (1979) The effects of the $\alpha$-glucosidase inhibitor Bay g 5421 (acarbose) on postprandial blood glucose, serum insulin, and triglyceride levels: Dose-time-response relationships in man. Res Exp Med 175: $87-94$

5. Schöffling K, Hillebrand I, Berchtold P (1980) Treatment of diabetes mellitus with the glucoside hydrolase inhibitor acarbose (Bay g 5421) Fron Horm Res 7: 248-257

6. Fölsch UR, Ebert R, Creutzfeldt W (1981) Response of serum levels of gastric inhibitory polypeptide and insulin to sucrose ingestion during long-term application of acarbose. Scand J Gastroenterol 16: 629-632

7. Sjöström L, William-Olsson T (1981) The effects of a new glyco- side hydrolases inhibitor on glucose and insulin levels during sucrose loads in obese subjects. Current Therp Res 30:351-366

8. Crey NJ, Goldring S, Kipnis DM (1970) The effect of fasting, diet, and Actinomycin D on insulin secretion in the rat. $J$ Clin Invest 49: 881-889

9. Bosboom RS, Zweens J, Bouman PR (1973) Effects of feeding and fasting on the insulin secretory response to glucose and sulfonylureas in intact rats and isolated perfused rat pancreas. Diabetologia $9: 243-250$

10. Idahl L-A (1973) Dynamics of pancreatic B-cell responses to glucose. Diabetologia 9: 403-412

11. Fink G, Gutman RA, Cresto JC, Selawry H, Lavine R, Recant L (1974) Glucose-induced insulin release patterns: effect of starvation. Diabetologia 10: 421-425

12. Efendić S, Cerasi E, Luft R, Glandnikoff G (1976) Potentiation of glucose-induced insulin release by glucose in the isolated pancreas of fed and fasted rats. Diabetes 25:949-954

13. Malaisse WJ, Malaisse-Lagae F, Wright PH (1967) Effect of fasting upon insulin secretion in rat. Am J Physiol 213: 843-848

14. Otsuki M, Sakamoto C, Yuu H, Maeda M, Morita S, Ohki A, Kobayashi N, Terashi K, Okano K, Baba S (1979) Discrepancies between the doses of cholecystokinin or caerulein-stimulating exocrine and endocrine responses in perfused isolated rat pancreas. J Clin Invest 63: 478-484

15. Otsuki M, Sakamoto C, Maeda M, Yuu H, Morita S, Baba S (1979) Effect of caerulein on exocrine and endocrine pancreas in the rat. Endocrinology 105: 1396-1399

16. Sakamoto C, Otsuki M, Ohki A, Yuu H. Maeda M, Yamasaki T, Baba S (1982) Glucose-dependent insulinotropic action of cholecystokinin and caerulein in the isolated perfused rat pancreas. Endocrinology 110: 398-402

17. Ceska M, Birath K, Brown B (1969) A new and rapid method for the clinical determination of $\alpha$-amylase activities in human serum and urine. Clin Chim Acta 26: 437-444

18. Desbuquois B, Aurbach GD (1971) Use of polyethyleneglycoal to separate free and antibody-bound peptide hormones in radioimmunoassay. J Endocrinol Metab 33: 732-738

19. Petersen $\mathrm{OH}$, Ueda N (1977) Secretion of fluid and amylase in the perfused rat pancreas. J Physiol 264: 819-835

20. Fölsch UR, Creutzfeldt W (1977) Pancreatic duct cells in rats: secretory studies in response to secretin, cholecystokinin-pancreozymin and gastrin in vivo. Gastroenterology 73: 1053-1059

21. Grossman MI, Greengard H, Ivy AC (1943) The effect of dietary composition of pancreatic enzymes. Am J Physiol 138: 676-682

22. Howard F, Yudkin J (1963) Effect of dietary change upon the amylase and trypsin activities of the rat pancreas. Br J Nutr 17: 281-294

23. Snook JT (1971) Dietary regulation of pancreatic enzymes in the rat with emphasis on carbohydrate. Am J Physiol 221: 1383-1387

24. Dagorn JC, Lahaie RG (1981) Dietary regulation of pancreatic protein synthesis 1 . Rapid and specific modulation of enzyme synthesis by changes in dietary composition. Biochim Biophys Acta 654: $111-118$

25. Lee PC, Brooks S, Lebenthal E (1982) Effect of fasting and refeeding on pancreatic enzymes and secretagogue responsiveness in rats. Am J Physiol 242 (Gastrointest Liver Physiol 5): G215-G221

26. Gray GM (1975) Carbohydrate digestion and absorption: Role of the small intestine. New Engl J Med 292: 1225-1230

27. Muller WA, Fallona GR, Unger RH (1971) The influence of the antecedent diet upon glucagon and insulin secretion. New Engl $J$ Med 285: 1450-1454

Received: 21 September 1982

and in revised form: 8 March 1983

Dr. M. Otsuki

Second Department of Internal Medicine

Kobe University School of Medicine

Kusunoki-cho, Chuo-ku

Kobe 650, Japan 